Jurnal Ilmu Dan Teknologi Kesehatan

Vol 6, No 1, September 2018,

ISSN: 2338-9095 (Print)

ISSN: 2338-9109 (online)

\title{
Asupan Zat Gizi Makro Penderita DM Tipe II yang Mengkonsumsi dan Tidak Mengkonsumsi Makanan Komersial Nihil Perbedaan
}

\author{
Sri Purnama ${ }^{1}$, Anang Wahyudi ${ }^{2}$ Jumiyati $^{3}$ \\ Poltekkes Kemenkes Bengkulu \\ sripurnama960202@gmail.com
}

\begin{abstract}
Artikel history
Dikirim, Jun $20^{\text {th }}, 2018$

Ditinjau, Aug 23 ${ }^{\text {rd }}, 2018$

Diterima, Aug $26^{\text {th }}, 2018$
\end{abstract}

\begin{abstract}
Diabetes mellitus is a metabolic disease group with hiperglikemi characteristics that occur due to abnormalities of insulin secretion, insulin work or both.Food play an important role in providing nutrition for diabetics.Intake of foods containing carbs, protein and fat is an important nutrient, extra food for diabetics in the form of low-calorie sugar, milk, biscuits, yogurt, whole wheat bread, oats are sold commercially. Objectives: To know the difference in intake of Nutrients Macro Against Diabetes mellitus type II Sufferers consume such foods because commercial foods providing nutrients according to needs, and deliver practical benefits. Method: This is an observational cross sectional design research. It was carried out in April-May 2018. Samples gathered at the RSUD Dr. M Yunus Bengkulu and selected by purposive sampling in accordance to inclusion and exclusion criteria. Total sample were 33 respondents. This research used the FFQ for intake data.The data were tested using the Kolmogorov-Smirnov test, independent t-test. Results: The majority of respondents were women. Respondents who choose to consume commercial foods were $63.6 \%$, the rest $(36.4 \%)$ chose not to consume commercial food. The results of this research obtained no difference between macro-nutrients intake in diabetes mellitus type II patient that consumes commercial and non commercial food ( $p$ value: 0.32), energy intake ( $p$ value: 0.67), protein intake ( $p$ value: 0.94) and fat intake ( $p$ value: 0.11) carbohydrates intake. Conclusion : Diabetics mellitus patients can consume commercial foods recommended for diabetes mellitus diet.
\end{abstract}

Keywords: Diabetes Mellitus, Commercial Food, Energy Intake, Protein, Fa,; Carbohydrate

\begin{abstract}
ABSTRAK
Diabetes melitus merupakan suatu kelompok penyakit metabolik dengan karateristik hiperglikemi yang terjadi karena kelainan sekresi insulin, kerja insulin atau kedua-duanya. Makanan memegang peranan penting dalam memberikan nutrisi bagi penderita diabetes. Asupan makanan yang mengandung karbohidrat, protein dan lemak merupakan nutrisi yang penting, Makanan tambahan bagi penderita diabetes berupa gula rendah kalori, susu, biskuit, roti gandum, yogurt, oat yang dijual secara komersial. Tujuan: Untuk mengetahui Perbedaan Asupan Zat Gizi Makro Terhadap Penderita Diabetes Melitus Tipe II mengkonsumsi makanan komersial dikarenakan makanan tersebut tetap
\end{abstract}


memberikan nutrisi sesuai kebutuhan, praktis dan memberikan manfaat. Metode: Desain penelitian adalah observasional dengan rancangan cross sectional. Penelitian ini dilaksanakan pada bulan April sampai bulan Mei tahun 2018. Lokasi penelitian di RSUD Dr. M Yunus Bengkulu. Sampel penelitian dipilih secara purposive sampling sesuai dengan kriteria inklusi dan eksklusi. Jumlah sampel 33 responden. Penelitian ini menggunakan FFQ untuk melihat asupan. Data diuji menggunakan Kolmogorov smirnov, uji $t$ test independent. Hasil: Sebagian besar responden berjenis kelamin perempuan. Responden yang memilih untuk mengkonsumsi makanan komersial 63,6\% dan responden memilih untuk tidak mengkonsumsi makanan komersial 36,4\%. Hasil penelitian ini didapatkan tidak ada perbedaan asupan zat gizi makro antara penderita diabetes melitus tipe II yang mengkonsumsi makanan komersial dan tidak mengkonsumsi makanan komersial dengan $(P$ value 0.32$)$ asupan energi, $(P$ value 0.67$)$ asupan protein, $(P$ value 0,94$)$ asupan lemak dan $(P$ value 0,11$)$ asupan karbohidrat. Kesimpulan: Penderita diabetes melitus dapat menjalankan diet dengan mengkonsumsi makanan komersial yang dianjurkan sesuai dengan diet diabetes melitus.

Kata Kunci: Diabetes Melitus, Makanan Komersial, Asupan Energi, Protein, Lemak, Karbohidrat

\section{PENDAHULUAN}

Masyarakat Indonesia lebih mengenal penyakit diabetes melitus dengan sebutan penyakit gula darah atau kencing manis. Menurut ADA (American Diabetes Assosiation) dalam Perkeni 2011, diabetes melitus merupakan suatu kelompok penyakit metabolik dengan karateristik hiperglikemi yang terjadi karena kelainan sekresi insulin, kerja insulin atau keduaduanya. Penyakit degeneratif ini merupakan salah satu masalah kesehatan dunia (Paruntu, 2012).

Berdasarkan data dari WHO (World Health Organitation) dalam perkeni melaporkan penderita diabetes melitus meningkat empat kali lipat dari tahun 1980-2014. Pada tahun 2014 ada sekitar 8,5\% penduduk dunia atau 422 juta orang dewasa menderita diabetes melitus. IDF (International Diabetes Federation) telah memprediksi adanya kenaikan jumlah penyandang diabetes di Indonesia dari 9,1 juta ditahun 2014 menjadi 14,1 juta pada tahun 2035 mendatang (Paruntu, 2012).

Menurut Perkumpulan Endokrinologi Indonesia (PERKENI, 2015) diperkirakan terjadi kenaikan jumlah penyandang diabetes di Indonesia dari 8,4 juta pada tahun 2000 menjadi sekitar 21,3 juta pada tahun 2030. Ini menunjukkan bahwa adanya peningkatan penderita diabetes sebanyak 2-3 kali lipat pada tahun 2035. Rata-rata prevalensi diabetes didaerah urban untuk usia diatas 15 tahun sebesar $5,7 \%$. Sedangkan prevalensi toleransi glukosa terganggu (TGT) berkisar antara $4,0 \%$.

Menurut hasil Riset Kesehatan Dasar (RISKESDAS, 2013) prevalensi diabetes melitus untuk Propinsi Bengkulu mengalami peningkatan $1,1 \%$ pada tahun 2007 menjadi 2,1\% pada tahun 2013 dari 
total jumlah penduduk di Propinsi. Menurut CDC dalam Widowati penderita diabetes yang paling banyak ditemukan ialah diabetes melitus tipe II, dari keseluruhan terdapat $90-95 \%$ nya adalah penderita diabetes tipe II.

Penyakit diabetes ini ditandai dengan kadar gula darah yang tinggi (hiperglikemia). Hiperglikemia dapat tidak terdeteksi karena penyakit diabetes tidak menimbulkan gejala (asimtomatik) dan disebut sebagai silent kiler dan menyebabkan kerusakan vaskular sebelum penyakit terdeteksi (Harianti et.al, 2017).

Makanan memegang peranan penting dalam memberikan nutrisi bagi penderita diabetes. Asupan makanan yang mengandung karbohidrat, protein dan lemak merupakan nutrisi yang penting. Karbohidrat, protein dan lemak akan memberikan energi yang akan digunakan bagi tubuh. Namun asupan zat gizi makro tersebut harus memiliki batasan untuk dikonsumsi sehari-hari karena dapat meningkatkan kadar gula darah didalam tubuh. Seperti asupan karbohidrat 45-60\%, protein $10-20 \%$ dan lemak 10-20\% dalam sehari. Pemilihan jenis makanan perlu diperhatikan untuk pemenuhan asupan sehari-hari (Tumiwa \& Langi, 2010).
Pengetahuan juga mempengaruhi asupan sehari-hari penderita diabetes. Dimana gaya hidup yang serba canggih, santai, dan instan sehingga mempengaruhi pemilihan jenis makanan yang dikonsumsi sehari-hari (Amalia et.al, 2016) Misalnya berbagai produk khusus untuk menambah nutrisi pada penderita diabetes seperti susu, gula rendah kalori, oat, roti, biskuit dll.

Gula rendah kalori memberikan mamfaat yang baik untuk penderita diabetes seperti, memberikan rasa manis namun dengan kalori yang rendah sehingga tidak mempengaruhi kadar gula darah, aman bagi penderita diabetes, mencegah kerusakan gigi dan menghambat pertumbuhan bakteri dimulut, membantu memperbaiki pencernaan dan meredakan sakit perut, baik untuk mengatur berat badan, untuk membatasi makanan manis berkalori tinggi (Raini \& Isnawati, 2011).

Banyak manfaat didalam makanan komersial membuat penderita diabetes tertarik mengkonsumsinya sebagai menu pelengkap diet. Namun tidak semua penderita diabetes di masyarakat mengkonsumsi makanan komersil. Banyak masyarakat yang tetap melakukan pengendalian penyakit diabetes dengan diet, salah satunya mengkonsumsi makanan dari sumber bahan alami. Pola diet yang mencakup sumber karbohidrat, 
protein dan lemak alami menjadi strategi dalam menjaga nutrisi penderita diabetes. Asupan nutrisi yang didapatkan secara berbeda oleh penderita diabetes melitus berdasarkan pengetahuan yang didapat oleh penderita diabetes.

Berdasarkan survei awal yang dilakukan di RSUD Dr. M Yunus Bengkulu dengan melakukan wawancara pada 10 orang pasien. Dari 10 orang pasien tersebut $40 \%$ diantaranya rutin mengkonsumsi makanan komersil susu dan gula rendah kalori, $30 \%$ rutin konsumsi gula rendah kalori dan 10\% tidak mengkonsumsi makanan komersil.

Dari permasalahan diatas peneliti tertarik untuk mengetahui apakah terdapat perbedaan asupan zat gizi makro terhadap penderita diabetes melitus tipe II mengkonsumsi makanan komersil dan tidak konsumsi di rawat jalan RSUD Dr. M Yunus Bengkulu.

\section{METODE}

Penelitian dilakukan di instalasi rawat jalan Poli Penyakit Dalam RSUD Dr. M Yunus Bengkulu yang dilakukan pada bulan April-Mei 2018. Penelitian menggunakan desain penelitian observasional dengan pendekatan cross sectional. Populasi penelitian ini adalah semua pasien DM tipe II yang berkunjung di poli penyakit dalam RSUD Dr. M Yunus Bengkulu dengan teknik pengambilan yaitu dengan purposive sampel. sampel dalam penelitian berjumlah 33 rsponden.

Pengumpulan data dengan cara wawancara langsung menggunakan form semi-FFQ. Wawancara dilakuka untuk mendapatkan asupan responden 1 bulan terakhir.

\section{HASIL DAN PEMBAHASAN}

Karateristik penderita diabetes melitus tipe II terdiri dari jenis kelamin, umur, pekerjaan dan asupan makanan (Tabel 1) Penderita diabetes melitus tipe II sebagian besar berjenis kelamin perempuan $(54,5 \%)$, dari segi umur penderita diabetes yang berkunjung kebanyakan berusia 45-54 tahun $(39,4 \%)$. Karena penderita diabetes melitus didominasi oleh perempuan maka sebagian besar pekerjaan responden ialah ibu rumah tangga $(39,4 \%)$ dan sebagian besar penderita diabetes melitus $(63,6 \%)$ memilih untuk mengkonsumsi makanan komersial sebagai penambah asupan. 
Tabel 1. Karateristik sampel

\begin{tabular}{|c|c|c|c|}
\hline \multicolumn{2}{|l|}{ Kategori } & $\mathbf{n}$ & $\%$ \\
\hline \multicolumn{4}{|l|}{ Jenis Kelamin } \\
\hline Perempuan & & 18 & 54,5 \\
\hline Laki-laki & & 15 & 45,5 \\
\hline Total & & 33 & 100 \\
\hline \multicolumn{4}{|l|}{ Umur } \\
\hline 45-54 tahun & & 13 & 39,4 \\
\hline 55-64 tahun & & 12 & 36,4 \\
\hline 65-74 tahun & & 7 & 21,2 \\
\hline 75-80 tahun & & 1 & 3 \\
\hline Total & & 33 & 100 \\
\hline \multicolumn{4}{|l|}{ Pekerjaan } \\
\hline IRT & & 13 & 39,4 \\
\hline PNS & & 7 & 21,2 \\
\hline Petani & & 2 & 6,1 \\
\hline Pensiunan & & 2 & 6,1 \\
\hline Pedagang & & 4 & 12,1 \\
\hline Swasta & & 4 & 12,1 \\
\hline Wirausaha & & 1 & 3 \\
\hline Total & & 33 & 100 \\
\hline \multicolumn{4}{|l|}{ Asupan } \\
\hline Konsumsi & Makanan & 12 & 36,4 \\
\hline \multicolumn{4}{|l|}{ Komersial } \\
\hline Konsumsi Makanan K & ersial & 21 & 63,6 \\
\hline Total & & 33 & 100 \\
\hline
\end{tabular}

Tabel 2. Rata-Rata Asupan Zat Gizi Pada Penderita Diabetes Melitus Tipe II Di Instalasi Rawat Jalan RSUD Dr. M Yunus Bengkulu Tahun 2018

\begin{tabular}{cccc}
\hline \multirow{2}{*}{ Variabel } & $\begin{array}{c}\text { Konsumsi } \\
\text { Komersial }\end{array}$ & $\begin{array}{c}\text { Tidak Konsumsi } \\
\text { Komersial }\end{array}$ & \multirow{2}{*}{$\boldsymbol{P}$ value } \\
\cline { 2 - 3 } & Mean \pm SD & Mean \pm SD & \\
\hline Asupan Energi & $1209,21 \pm 409,23$ & $1050,87 \pm 267,89$ & 0,32 \\
\hline Asupan Protein & $45,27 \pm 20,59$ & $33,90 \pm 17,61$ & 0,67 \\
\hline Asupan Lemak & $42,30 \pm 16,29$ & $37,43 \pm 16,29$ & 0,94 \\
\hline Asupan KH & $163,45 \pm 58,17$ & $132,64 \pm 43,60$ & 0,11 \\
\hline
\end{tabular}

Hasil penelitian (Tabel 2) menunjukkan bahwa rata-rata asupan energi penderita Diabetes Melitus tipe II yang mengkonsumsi makanan komersial yaitu 1209,21 kkal dengan nilai SD 409,23. Rata-rata asupan protein $45,27 \mathrm{gr}$ dengan nilai SD 20,59. Rata-rata asupan lemak 42,30gr dengan nilai SD 16,29. Rata-rata asupan karbohidrat 163,45 gr dengan nilai SD 58,17. 
Hasil penelitian (Tabel 3) menunjukkan bahwa rata-rata asupan energi penderita DM tipe II yang tidak mengkonsumsi makanan komersial yaitu 1050,87kkal dengan nilai SD 267,89. Rata-rata asupan protein yaitu 33,90gr dengan nilai SD 17,61. Rata-rata asupan lemak 37,43 gr dengan nilai SD 16,29. Rata-rata asupan karbohidrat yaitu 132,64gr dengan nilai SD 43,60 .

Tabel 3. Perbedaan Asupan Zat Gizi Makro Pada Penderita DM Tipe II.

\begin{tabular}{ccccc}
\hline \multirow{2}{*}{ Variabel } & \multirow{2}{*}{$\mathbf{N}$} & \multicolumn{3}{c}{ Tidak Konsumsi Makanan Komersial } \\
\cline { 3 - 5 } & & Min & Max & Mean \pm SD \\
\hline Asupan Energi & 12 & 665 & 1514 & $1050,87 \pm 267,89$ \\
Asupan Protein & 12 & 13 & 69 & $33,90 \pm 17,61$ \\
Asupan Lemak & 12 & 23 & 75 & $37,43 \pm 16,29$ \\
Asupan KH & 12 & 96 & 256 & $132,64 \pm 43,60$ \\
\hline
\end{tabular}

Berdasarkan hasil analisis uji t-test independent menunjukkan bahwa tidak ada perbedaan asupan energi penderita Diabetes Melitus tipe II yang mengkonsumsi makanan komersial dengan tidak mengkonsumsi. Hal ini dibuktikan nilai $p$ value $0,32(<0,05)$ untuk asupan energi, sedangkan $p$ value $0,67 \quad(<0,05)$ untuk asupan protein, $p$ Value 0,94 $(<0,05)$ untuk asupan lemak dan tidak ada perbedaan asupan karbohidrat penderita diabetes dengan $p$ Value $0,11(<0,05)$.

Berdasarkan hasil uji statistik, tidak ada perbedaan asupan zat gizi makro (energi, protein, lemak dan karbohidrat) pada penderita diabetes melitus tipe II yang mengkonsumsi dan tidak mengkonsumsi makanan komersial. Sebanyak 63,6\% responden memilih untuk mengkonsumsi makanan komersial dan sisanya memilih untuk tidak mengkonsumsi makanan komersial 36,4\%.

Hasil penelitian ini terkait dengan penelitian yang dilakukan di Amerika bahwa orang yang mengkonsumsi pemanis tambahan (stevia/aspartam) tidak memiliki perbedaan asupan kalori (Anton et al., 2010). Untuk tingkat kenyang responden melaporkan bahwa memiliki tingkat kenyang yang sama walaupun diberi pemanis tambahan dengan jenis yang berbeda. Berbeda dengan responden yang diberi pemanis sukrosa akan memiliki asupan kalori lebih banyak dibandingkan dengan responden yang mengkonsumsi stevia/aspartam. Perbedaan ini karenakan sukrosa yang dikonsumsi mengandung 
kalori yang tinggi dibandingkan dengan stevia/aspartam (Anton et al., 2010).

Rata-rata asupan penderita diabetes melitus tipe II yang mengkonsumsi makanan komersial ialah asupan energi 1209,21kkal, protein 45,27gr, lemak 42,30gr, karbohidrat $163,45 \mathrm{gr}$. Sedangkan rata-rata asupan penderita diabetes melitus tipe II yang tidak mengkonsumsi makanan komersial ialah energi $1050,87 \mathrm{kkal}$, protein $33,90 \mathrm{gr}$, lemak 37,43gr, karbohidrat 132,64 gr.

Makanan komersial seperti produk gula dalam satu saset menghasilkan energi $5 \mathrm{kkal}$, lemak, protein dan karbohidrat 0gr. Sedangkan produk susu satu porsinya $60 \mathrm{gr}$ bubuk susu dengan kalori 260kkal, protein 10gr, lemak 7gr, dan karbohidrat 39gr. Gula ini juga tidak rusak pada suhu tinggi seperti sakarin atau aspartam. Steviosid tahan pada pemanasan hingga $200^{\circ} \mathrm{C}$ $\left(392^{\circ} \mathrm{F}\right)$, sehingga dapat digunakan pada hampir semua resep makanan (Raini \& Isnawati, 2011).

Penelitian lain menunjukkan manfaat konsumsi susu sebagai asupan tambahan harian secara signifikan dikaitan dengan penurunan kejadian diabetes melitus sebesar 4-9\%. ${ }^{(4)}$ Penelitian kalergis mengatakan jika konsumsi susu 2 porsi sehari pada remaja maka dapat menurunkan resiko diabetes tipe II sebesar $38 \%$ (Kalergis et.al, 2013).

Penderita diabetes melitus yang tidak mengkonsumsi makanan komersial memiliki asupan protein lebih rendah karena mereka memiliki kepercayaan bahwa dengan mengkonsumsi protein maka kadar gula darah akan naik. padahal konsumsi protein secara cukup akan merangsang sekresi insulin terutama pada orang yang menderita diabetes melitus. Ketika protein diberikan secara bersamaan dengan glukosa, insulin dapat menangkap glukosa dengan baik sehingga glukosa didalam darah berkurang. Respon insulin sejalan dengan protein yang dikonsumsi. Protein juga dapat merangsang peningkatan konsentrasi insulin sejalan dengan jumlah protein yang dikonsumsi.

Asupan zat gizi makro akan mempengaruhi kadar gula darah, hal ini seperti penelitian Paruntu yang mengatakan bahwa penderita diabetes melitus tipe II dengan asupan energi melebihi kebutuhan memiliki resiko 31 kali lebih besar untuk mengalami kadar gula tidak terkendali dibandingkan dengan penderita diabetes yang asupannnya sesuai dengan kebutuhan. ${ }^{(8)}$

Protein yang dikonsumsi sehari akan mempengaruhi kadar gula darah. Hal ini sesuai dengan penelitian yang dilakukan 
oleh Muliani bahwa pasien dengan asupan protein yang baik mengalami penurunan kadar gula darah sedangkan asupan protein kurang baik menyebabkan kadar gula tidak terkendali. Dari hasil uji statistik menunjukkan bahwa terdapat hubungan yang bermakna antara asupan protein dengan kadar gula darah penderita diabetes. $^{(7)}$

Asupan lemak pada penderita diabetes melitus tipe II yang melebihi kebutuhan sehari akan berpengaruh terhadap kadar gula darah. Berdasarakan penelitian yang dilakukan oleh Paruntu di bahwa asupan penderita diabetes dengan kadar glukosa darah tidak terkendali sebagian besar diakarekan asupan lemak melebihi kebutuhan. Asupan lemak penderita diabetes yang melebihi kebutuhan memiliki risiko 5 kali lebih besar untuk tidak mampu mengendalikan kadar glukosa darah diabandingkan dengan pengidap diabetes yang asupan lemak sesuai dengan kebutuhan ( Paruntu, 2012).

Asupan karbohidrat pada penderita diabetes dianjurkan untuk tidak melebihi kebutuhan sehari. Hasil penelitian yang dilakukan oleh Mulian berdasarkan uji statistik bahwa ada hubungan yang bermakna antara asupan karbohidrat dengan kadar gula darah (Harianti et.al, 2017). Penelitian oleh Paruntu juga menunjukkan bahwa penderita diabetes melitus tipe II yang memiliki asupan karbohidrat melebihi kebutuhan cenderung tidak mampu melakukan pengendalian kadara glukosa darah dibandingkan dengan asupan karbohidrat sesuai dengan kebutuhan (Muliani, 2013).

Menjaga pola makan dianjurkan agar dapat terhindar dari diabetes terutama diabetes melitus tipe II dengan cara mengkonsumsi lemak dan karbohidrat cukup dan meningkatkan konsumsi serat. Jumlah serat yang dianjurkan untuk dikonsumsi yaitu 15-20gram/1000kkal setiap harinya (Azridamailiza, 2011).

Terapi gizi medis menurut Tumiwa dan Langi merupakan komponen penting dalam pilar penatalaksanaan diabetes dengan tujuan mencegah dan memperlambat komplikasi kronis dari terapi gizi medis bersifat individual dengan mempertimbangkan kebiasaan makan setempat, metabolisme, aktifitas fisik dan adanya komorbid. Komposisi makronutrien yang direkomendasikan pada pasien diabetes adalah karbohidrat 45-60\%, protein $10-20 \%$, lemak tak jenuh ganda 10$20 \%$, lemak tak jenuh tunggal 5-10\% dan lemak jenuh 5-10\% dan anjuran untuk mengkonsumsi jenis karbohidrat dengan indeks glikemik rendah (Tumiwa \& Langi, 2010). 
Penelitian ini menggunakan kuesioner semi FFQ untuk melihat asupan penderita diabetes melitus satu bulan terakhir. Semi FFQ sangat baik digunakan karena selain bisa menentukan asupan zat gizi perhari individu juga dapat menjadi alat yang baik dalam menilai diet dalam berbagai aturan epidemiologi (Asmawati et.al, 2013).

\section{SIMPULAN}

Rata-rata asupan zat gizi makro penderita DM tipe II di Instalasi RSUD Dr. M Yunus Bengkulu yang mengkonsumsi makanan komersial yaitu asupan energi 1209,21kkal (64\% dari kebutuhan), protein 45,27gr (79\% dari kebutuhan), lemak 42,30gr (80\% dari kebutuhan), karbohidrat 163,45gr (57\% dari kebutuhan).

Rata-rata asupan zat gizi makro penderita DM tipe II di Instalasi Rawat Jalan RSUD Dr. M Yunus Bengkulu yang tidak mengkonsumsi makanan komersial yaitu asupan energi 1050,87 kkal (55\% dari kebutuhan), protein 33,90 gr (59\% dari kebuthan), lemak 37,43 gr $(71 \%$ dari kebutuhan), karbohidrat 132,64 gr (47\% dari kebutuhan).

Tidak ada perbedaan asupan zat gizi makro penderita DM tipe II di RSUD Dr. M Yunus Bengkulu seperti yang dilihat jika $p$ value $(0,32)$ untuk asupan energi, $p$ value $(0,67)$ untuk asupan protein, $p$ value $(0,94)$ untuk asupan lemak, p value $(0,11)$ untuk asupan karbohidrat.

Diharapkan bagi penderita diabetes melitus yang berkunjung di RSUD Dr. M Yunus Bengkulu untuk berkonsultasi gizi ke ahli gizi untuk memilih diet yang tepat dengan tujuan memperbaiki pola makan dan menghilangkan kepercayaan bahwa protein penyebab naiknya kadar gula darah serta dapat mengkonsumsi protein yang cukup untuk asupan sehari-hari.

\section{DAFTAR RUJUKAN}

Amalia, Sutikno, \& Nugraheni, 2016. Hubungan Antara Tingkat Pengetahuan Tentang Diabetes Mellitus Dan gaya Hidup Dengan Tipe Diabetes Mellitus Di Puskesmas Wonodadi Kabupaten Blitar. Institut Ilmu Kesehatan Bhakti Wiyata Kediri. Vol 1 Juni 2016)

Anton et al., 2010. Effects Of Stevia, Aspartame, And Sucrose On Food Intake, Satiety, And Postprandial Glucose And Insulin Levels. Jurnal Home Page ww.elsevier.com/locate/appet)

Asmawati, Indriasari, \& Najamuddin, 2013. Studi Validasi SemiQuantitatif Food Frequency Quetionnaire (FFQ) Dan Recall 24 Jam Terhadap Asupan Zat Gizi Makro Ibu Hamil Di Puskesmas Kassi-Kassi Kota Makassar. Program studi ilmu gizi kesehatan makassar UNHAS, Makassar)

Azridamailiza, 2011. Asupan Zat Gizi Dan Penyakit Diabetes Mellitus. Studi 
Literatur, Jurnal Kesehatan Masyarakat, September 2011-Maret 2011, Vol. 6, No. 1)

Harianti, Nyorong, \& A.Fachrin, 2017. Analisis Faktor-Faktor Yang Berhubungan Dengan Kadar Gula Darah Penderita DM Tipe II Di RSUD Makassar Tahun 2017. Makassar; Volume 11 Nomor 4 Tahun 2017)

Kalergis, Yinko, Nedelcu, March, \& Israel, 2013. Dairy Product And Prevention Of Type 2 Diabtes; Implications For Research And Practice. Mini Review Article; Volume 4 Article 9023 July 2013.)

Muliani, 2013. Asupan Zat-Zat Gizi Dan Kadar Gula Darah Penderita DM Tipe II Di Poliklinik Penyakit Dalam RSUD Dr. H Abdul Moeloek Propinsi Lampung. Jurusan Gizi Poltekkes Kemenkes Tanjungkarang. Volume IV Nomor 2 hlm 325-332)
Paruntu, 2012. Asupan Gizi Dengan Pengendalian Diabetes Pada Diabetesi Tipe II Rawat Jalan Di BLU Prof. DR.R.D.Kandou Manado. Jurusan Gizi Politeknik Kesehatan Manado. GIZIDO Volume 4 Nomor 1 Mei 2012)

PERKENI, 2015. Konsesus Pengelolaan dan9Pencegahan Diabetes Melitus Tipe II di Indonesia. PB. Perkeni)

Raini \& Isnawati, 2011. Artikel Kajian; Khasiat Dan Keamanan Stevia Sebagai Pemanis Pengganti Gula Safety And Effect Of Stevia As A Sweetener). Media Litbang Kesehatan Volume 214 Tahun 2011)

RISKESDAS, 2013. Riset Kesehatan Dasar. Badan Penelitian Dan Pengembangan Kesehatan Kementerian Republik Indonesia)

Tumiwa \& Langi, 2010. Terapi Gizi Medis Pada Penderita Diabetes Melitus. Jurnal Biomedik, Volume 2, Nomor 2, hlm. 78-87) 